\title{
Building Children's Critical Thinking by Puzzle Story Telling
}

\author{
Elise Muryantia ${ }^{a}$, Yuli Herman ${ }^{b}$ \\ ${ }^{a}$ Universitas Negeri Padang, Padang, Indonesia \\ ${ }^{\mathrm{b} U n i v e r s i t a s}$ Muhammad Yamin Solok, Solok, Indonesia \\ Corresponding e-mail: elisemuryanti@yahoo.com
}

\begin{abstract}
Critical thinking is a crucial skill for children as the future of human resources. Children as a human generation should be able to think critically and build knowledge as the fundamental construction. This means that children should be able to analyse into several sights for problem solving. Puzzle story can be an aid for critical thinking scaffolding. Children organize the stories selection based on their own imagination. Teacher provides children with an example of starting direction while the rest and the end of the stories are organized by children as an active story organizer and story teller. This way provides them a hook for creative thinking. Puzzle stories can help children to think creatively and analyse the situation and problem in the several alternatives directions. The research has been conducted in the Kindergarten in Duri, Riau Province. This research is a descriptive qualitative research. The researchers found that most of the students $(86.6 \%)$ were able to deliver stories based on their own arrangement. It indicates that the children are able to think critically in developing ideas.
\end{abstract}

Keywords: critical thinking, puzzle story telling

\section{INTRODUCTION}

Early childhood is a critical age in human development. The future of human resources depends on the quality of the children as national assets. Children are future generations, they will take a part in the pivotal sectors or they will become the leaders in society. For that reason, it is very important to prepare children with an ability to be critical and becoming good problem solvers.

Smart Children should be able think critically and analytically and criticize to the environment. The skill of critical thinking is crucial for adult and the early age is an initial phase in building this skill. Critical thinking plays an important role for human in order to gaetsuccessful in career and in socialisation. It can be seen that a criticize child will ask a lot of questions to all the things surrounding. Therefore, teachers and parents should be able to provide a hook to stimulate children to be critical and analytical.

Critical thinking began in the early ages or the ages of the children before they start studying at school. If children have ability to be analytic, they can view the nature as the scientific creation that is created by the great creature and the universe is a part of nature that cannot be created by human. The critical and analytic children like to ask questions to all the things they find in environment. It may be a lot of questions come to critical children's mind. Adults should be available to stimulate children to be critical and build the concept and become more analytic in problem solving because critical and analytical skills are necessary for children's maturity process.

Critical thinking refers to a problem solving activity that involve the mental process (Steiberg as cited in Lippman, 1987). Moreover, Willingham (2008) states that critical thinking is a necessary skill that need regular practice. Practice and background knowledge are important elements to organize a logical problem solving. Furthermore, Murphy (2014) claims that children are motivated to create an abstract thinking and the topic of being discussed in text material or books, this way is an aid to build their early concept and comprehension of the subject matter. 
In addition Lipman (1991) as cited in Murphy et al (2014) state that critical thinking is a relevancy and consistency in providing judgement, criteria based on self-corrections and sensitive to the current situation. Furthermore, Atkinson (1997) describes notion of human cognitive learning is in the experiential context of the real world of the high context, the critical and complex cognitive skills are conceptualized. Children learn and develop their cognitive knowledge through the real context and experiences. The concept of object concrete and abstract learn naturally in life. Children gain knowledge from the basic to the complex by playing and experiencing objects in nature. The experiences can be fundamental factors of becoming critical and analytic children.

Schools and kindergarten must have an effective way to provide young age children to be critical. This skill is very important to help children to develop the ways of thinking and problems solving. Story telling is one of the strategy that can be implemented to develop children's critical thinking. Through Stores telling, teachers can create some activities which can trigger children to think critically. Of course the activities should be done based on the children's mood while playing or acting.

This research is conducted to answer a question to what extent a puzzle story telling build children's critical thinking. Story will not only be used as a strategy that can attract the children attention and passion in learning, but it will also be implemented to build their critical thinking. The children will get involved in the creating and arranging a story by solving some puzzles provided in the story. The result of the research can be a valuable input for kindergarten teachers and early childhood education practitioners to implement puzzle stories for constructing children's critical thinking.

\section{REVIEW OF RELATED LITERATURE}

Children like to listen to a story. Usually parents tell a story to their children before they go to bed. Story is important to build children imagination such as imaging animals, scenery, cities, or landscapes. Children can understand the meaning of utterances by telling and listening to stories. Through speaker's intonation, children can figure out the meaning or image of something. Ochs et all ( 1992) describe that a story has three dimensions; temporal which provides the figure situation, from past, present to future, configurationally dimension or the order of the information structure, grammar, vocabularies, intonation and the quality of the speakers' voice and problem solving dimension relates to the causal connection to the narrative event. The structure of the stories contain the linguistic elements such as how the sentences arranged in acceptable structure (grammar), word choice (vocabularies or lexical items), and the presentation with the intonation, tempo and voice quality. It can be argued that story telling is a good practice for children's linguistics proficiency.

Furthermore, children will be interested to listen to story and it is also crucial to build their imagination as well as to activate their brain to work. Saxe, Gabrieli and Scholz (2009) pointed out that storytelling could activate the brain region in mental section in describing characters, desires, thought, hopes, and good belief more than describing physical section such as telling and explaining objects in older children. However, younger children indicated that storytelling affected their left and right brain in both mental and physical section. It can be argued that storytelling affects children's brain and stimulate left brain and right brain function more to young children compared to older children.

Storytelling is also beneficial for building children's perception on moral standard. By telling certain stories adult can teach children about politeness, respect, and other moral values. Stories also provide children the discourse of the language skills and provide them the reality and the knowledge of the world (Schneider \& Hayward, 2010). Miller et al (1997) found in their research that both Chinese family and American family used personal storytelling to teach moral and social standard as well as building children's critical analysis. The research showed that Chinese family used more frequently personal types of storytelling compared to the American family. The literature reviews above underpin that story telling is a method that can be used to develop children's intelligence and critical thinking and also a good way to impart moral, and ethics, and good behaviour.

Shen and Malek (2010) has designed digital puzzle tale for storytelling. The researchers found that digital puzzle tales can be an interaction tool. The result of the implementation of puzzle tales indicated that puzzle tales had a low level in mental demand, physical demand, temporal, effort and stress but high in performance. Then, Shen and Malek (2010) evaluated the use of puzzle tales for storytelling to 10 subjects. The result in qualitative 
analysis shows that puzzle tales provide an interactive story telling for the users where the users have fun and enjoy the stories.

Moreover, Mercer (2002) in his research found that children improve their problem solving after arranging the puzzle words and communicating the meaning of puzzles to others. Children make meaning from their conversation and stories following the sequence of puzzles and this build their communicative intelligence and problem solving.

There are some research has been conducted in storytelling and the implication to develop children's brain and developing children's behaviour, ethics and moral (Shen \& Malek, 2010) and a word puzzle (Merce, 2002). However, there is less research investigates the implementation of stories puzzle for constructing children's critical thinking. This research gap has been taken as my field of study. The researcher has an attempt to investigate the implementation of puzzle stories for children in difference discourse and setting. The study used puzzle stories is in the form of printed master pieces not in a digital version. The puzzle stories used as a media to train and construct children's linguistic critical thinking.

\section{METHOD}

This research is a descriptive qualitative research. In conducting this research, the researcher observed the teacher in the classroom. The research was conducted at an Islamic Kindergarten in Duri. The reason why the kindergarten has been selected because the Kindergarten has an accreditation " $A$ " in Duri region and this kindergarten has supported and imparted children critical thinking by implementing puzzles story in teaching literacy and technological and science. The research aims to observe the process of teacher in implementing puzzle story telling in a classroom practice and the process of children engage puzzles storytelling to build their critical thinking. The participants of the research were 20 students in class B2 with a teacher. The researcher observed the activities in the literacy centre while teacher was implementing a puzzle story telling activities. The instrument used to gather the data were observation notes such as field notes, and students' individual attainment in observation sheet to identify children critical thinking development. Then, the teacher was also interviewed to gain the deeper data and understanding as well as for a triangulation purpose.
The data was analysed by using the procedures of descriptive qualitative analysis of Miles and Huberman (1984) such as data reduction, data display, conclusion and drawing verification. Then the reality or the phenomena found is described, explained and critically interpreted in the form of narrative.

\section{FINDING AND DISCUSSION}

The research describes the process of implementation of puzzle story to kindergarten students at class B. The data was taken through observation during the teaching and learning process and teacher's evaluation and interview. During the process, the researcher took notes on students' participation and their ability in telling the story. From the data gathering, there were eight meetings used by the teacher implementing the serial pictures story; four meetings in literacy section and four meetings in technological and science section. Puzzle stories has been applied in literacy, technological and science section regularly twice a week.

In implementing a puzzle story, the teacher started the class by showing the students a set of pictures with four pictures in every set. Then, to check whether the students understood what were in the pictures, the teacher asked the students about the pictures. Once the teacher was certain that the students knew the picture, she, then, started telling the story based on the sequence of the serial. After she finished telling the story, the teacher randomized the pictures and asked the students to rearrange the sequence individually and told the story based on their own arrangement.

Based on the observation, the students at first hesitated to stand up to tell their own story. From 20 students, only half of them raised their hand to come forward to tell the story. When they told the story, most of them used single sentence on every picture. The following is the example of students' story on the picture series of a farmer and vegetable. 
Original Sequence

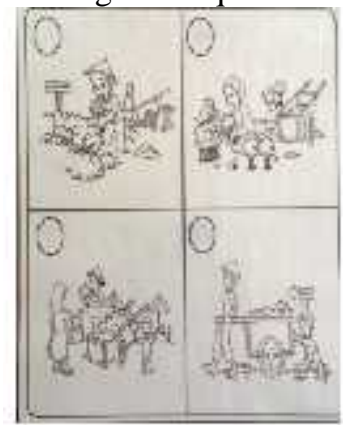

Student's Sequence

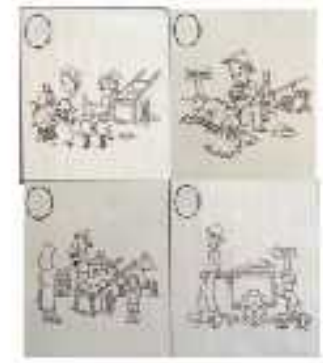

Figure 1. Students' story on the picture series of a farmer and vegetable

“Bu Tani memetik sayuran di kebun. Pak Tani juga memetik sayuran. Terus pak Tani membawa sayuran ke pasar. Terus, pak Tani menjual sayuran di Pasar"

(Mrs. Farmer picks the vegetable at the garden. Mr. Farmer also picks the vegetable. Then, Mr. Farmer brings the vegetables to the market. Then, Mr. Farmer sells the vegetables.)

Then, the other example is on the topic of "Where does the rice come from". The following is one of the examples of students' arrangement.
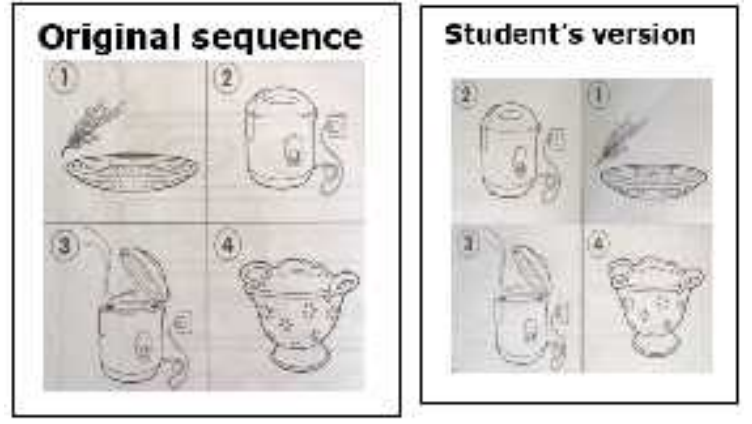

Figure 2. Where does the rice come from

Although the students could only use a single sentence on every picture, their story was still understandable and makes sense. On the second meeting, the teacher tried to find a solution of the students' self-confident. The solution was giving star stamp on the student hand if they could rearrange the sequence and told the story in front of the class. The reward technique seemed successful to persuade the students to raise their hand. There were only 2 students not actively raised their hand. The topic of the picture was "where the rice comes from". The third and the fourth meeting in literacy and technological and science sections were the challenge to reinforce and stimulate children to be more active and more critical in storytelling. Teachers in this phase required to encourage children more actively and paid attention to less active children. The less active children had more chance to tell the story from the puzzle provided.

In the fifth to the seventh meetings, the students were able to demonstrate a bit longer story. However, since the picture was not clear, especially the first picture which figured out the paddy, most of the students did not put this picture as the first sequence.

Although every picture consisted only one single picture, the students were able to use one to two sentences in telling the story. It seemed that they have already know how to create their own story based on the picture that they arranged.

Furthermore, at the end of every meeting, the teacher scored the students based on their performance by giving 4 stars, 3 stars, 2 stars or 1 star. Based on the teacher's evaluation, the students' basic ability was good as shown on the following table.

Table 1. percentage of students' achievement in arranging stories.

\begin{tabular}{llll}
\hline Meeting & $\begin{array}{l}\text { Good } \\
* * * *\end{array}$ & $\begin{array}{l}\text { Moderate } \\
* * *\end{array}$ & $\begin{array}{l}\text { Less } \\
* * / *\end{array}$ \\
\hline $\mathbf{1}$ & $80 \%$ & $10 \%$ & $10 \%$ \\
$\mathbf{2}$ & $86.6 \%$ & $13.3 \%$ & $0 \%$ \\
\hline
\end{tabular}

The table above indicates that the use serial picture as a media of teaching students in telling a story can be easily understood by the students. As shown on the table, at the first meeting from 20 students who attended the class, $16(80 \%)$ of them could make their own arrangement of the pictures and tell the class a short story based on the arrangement of the picture. While there was 2 students (10\%) who could do it moderately and another $10 \%$ who did it less. Then, on the second meeting, from 15 students who attended the class, $86.6 \%$ of them could deliver the story well and think more critically in developing the story and $13.3 \%$ who did it moderately. From the result it can be figured out that puzzle story could stimulate children's critical thinking as it is not a skill that can be constructed in a short time but it needs a regular practice as it proposed by Willingham (2008). The data from interview indicated that teacher practice puzzle story regularly and as the result children got improvement in storytelling and critical thinking.

The findings indicate that children have creativity and could make the puzzle becomes 
meaningful. They could activate their brain to arrange they puzzle to good start and creative stories ending. This finding underpin that children critical thinking could be stimulated by puzzles stories and this is similar to the result of Mercer (2002) who found that children has improved their problem solving after practicing and arranging the puzzle and communicating to others. It seems that puzzle stories could be the scaffolding to build children's communicative intelligence and problem solving. By doing this way, school has automatically helped students to develop their thinking. Certainly, the school has prepared the students to be more independent in form of thinking.

In addition, Ochs, et.al (1992) described that storytelling may help in perspective- taking, differentiating the 'ersion' and theories, being analytical or critical thinking, and theory reconstructing. This explanation confirms the result of this research, especially in building students' critical thinking. By providing the students with this skill, school will also prepare the students to have an ability to solve problems in their future life.

\section{CONCLUSION}

Puzzle story is an effective method to build children's critical thinking. It is not difficult to trigger early childhood students' critical thinking by implementing puzzle stories and ask children to elaborate and develop the story from the providing puzzle stories. By giving examples the students will be able to create their own arrangement of the story or even create a different story from their teacher's. The teacher should be able to think creatively in case the students do not have self- confident to tell a story in front of the class. By motivating them with a star stamp and stimulate with a credit and praise, the students will be motivated to tell the class their stories. It is expected that the implementation of puzzle stories to early childhood students, so the ability of being critical thinker in the future can be reached.

\section{REFERENCES}

Atkinson, D. (1997). A critical approach to critical thinking in TESOL. TESOL quarterly, 31(1), 71-94.

Lenox, S. Interactive Read-Alouds-An Avenue for Enhancing Children's Language for Thinking and Understanding: A Review of Recent
Research. Early Childhood Educ J (2013)

41:381-389 DOI 10.1007/s10643-013-0578-5

Lipman, M. (1987). Critical thinking: What can it be?.Analytic Teaching, $8(1)$.

Mccarthy,L., (1980) Teacher Education in a Multicultural Society. South Pacific Journal of Teacher Education, 8:1-2, DOI: $10.1080 / 0311213800080107$ To link to this article: http://dx.doi.org/10.1080/0311213800080107

Mercer, N. (2000). Words and minds: How we use language to think together. Psychology Press.

]Miller, P. J., Wiley, A. R., Fung, H., \& Liang, C. H. (1997). Personal storytelling as a

Medium of socialization in Chinese and American families. Child development, 68(3), 557-568.

Miles, M. B., \& Huberman, A. M. (1984). Drawing valid meaning from qualitative data: Toward a shared craft. Educational researcher, 13(5), 20-30.

Murphy, P.K, Rowe,M.L., Ramani,G., Silverman,R. (2014) Promoting Critical

Analytic Thinking in Children. EducPsychol Rev 26:561-578. DOI 10.1007/s10648-014-9281-3.

Ochs,E.,Taylor,C., Rudolp, D. ( 1992) . Story telling as a theory building activity. Discourse

Processes. 15,37-72 retrieved at

http://www.tandfonline.com/action/journalInformati on?journalCode $=$ hdsp 20

Saxe, R. R., Whitfield-Gabrieli, S., Scholz, J., \&Pelphrey, K. A. (2009). Brain regions for perceiving and reasoning about other people in school-aged children. Child development, 80(4), 1197-1209.

Schneider, P., \& Hayward, D. (2010). Who does what to whom: Introduction of referents in children's storytelling from pictures. Language, Speech, and Hearing Services in Schools, 41(4), 459-473.

Shen, Y. T., \& Mazalek, A. (2010). PuzzleTale: A tangible puzzle game for interactive Storytelling. Computers in Entertainment (CIE), 8(2), 11.

Willingham, D. T. (2008). Critical thinking: Why is it so hard to teach?. Arts Education Policy Review, 109(4), 21-32. 